\title{
The Effect of Value Stream Mapping Toward Operational in A Company
}

\author{
Asrat Sry Kandi Ovita Barus ${ }^{1} \quad$ Niken Sulistyowati $^{2}$ \\ 1.Graduate Student of Management Study Program, Mercu Buana University, Jakarta, Indonesia \\ 2.Lecturer on Master of Management Study Program, Mercu Buana University, Jakarta Indonesia
}

\begin{abstract}
The purpose of this study was to determine how the effect of value stream mapping on operational performance. Empirical data for this study was taken from a survey at PT PERTIWI AGUNG. PT PERTIWI AGUNG is engaged in the Pharmaceutical industry. The type of research according to the exploration is causal associative. The sampling technique used is probability sampling, which is a sampling technique that provides equal opportunities for each member of the population to be selected as a sample member. The data used are primary data derived from distributing questionnaires to PT PERTIWI AGUNG. Data analysis techniques using the Structural Equation Model (SEM) AMOS Version 22. Data testing uses validity and reliability tests. Normality Test, Model Suitability Test and Hypothesis Test. The results of the study show that there is an effect of value stream mapping on operational performance. Every increase of one unit of value stream mapping will increase operational performance by 0.841
\end{abstract}

Keywords: value stream mapping, operational performance, SEM, AMOS

DOI: $10.7176 / \mathrm{EJBM} / 12-18-07$

Publication date:June 30th 2020

\section{Introduction}

Each service and manufacturing company will continue to improve the productivity of the company in all aspects. In a manufacturing company. In the manufacturing industry, a company's productivity can be seen from the company's ability to carry out the production process effectively and efficiently. The more efficient the company's production system, the less waste will arise in their production activities. According to (Hines \& Taylor, 2000), one of the desired productivity parameters is to minimize the waste generated in each work process. A lot of waste will certainly hinder the business of the industry. Therefore, waste should be reduced in a production process.

Today, the development of existing technology can lead to very intense competition between companies. Many companies are starting to compete for maximum profits with low production costs. Manufacturing companies will continue to strive to increase production results by making improvements to the quality, price, quantity of production, and timely delivery to provide satisfaction to customers. The work done in the production of goods is to reduce waste that has no added value such as overproduction, waiting, transportation, processing wrongly, work in process, unnecessary movements, defective products, and creativity of employees who are not utilized.

\section{Literatur Review}

Value stream mapping is not just a neat tool for drawing that highlights waste, although it is certainly valuable, but this tool helps us see the associated process chains and describe lean value flows in the future, (Liker \& Meier, 2006), while according to (Womack \& Jones, 1996) Value stream mapping is a series of all specific actions needed to bring a certain product (either service products or a combination of both) through three important management tasks of any business.

Performance is a form of business activity or program initiated and implemented by the leadership of an organization or company to direct and control achievement, Ruky in (Rahani \& Al-Ashraf, 2012) Performance measurement is the most important activity for management in managing company organizations. In general, performance is defined as the extent to which an operation meets performance goals, and steps

\subsection{Framework}

Based on the background of research, research problems, and literature review that has been described previously, then in this study designed a research framework for the effect of value stream mapping on operational performance. 


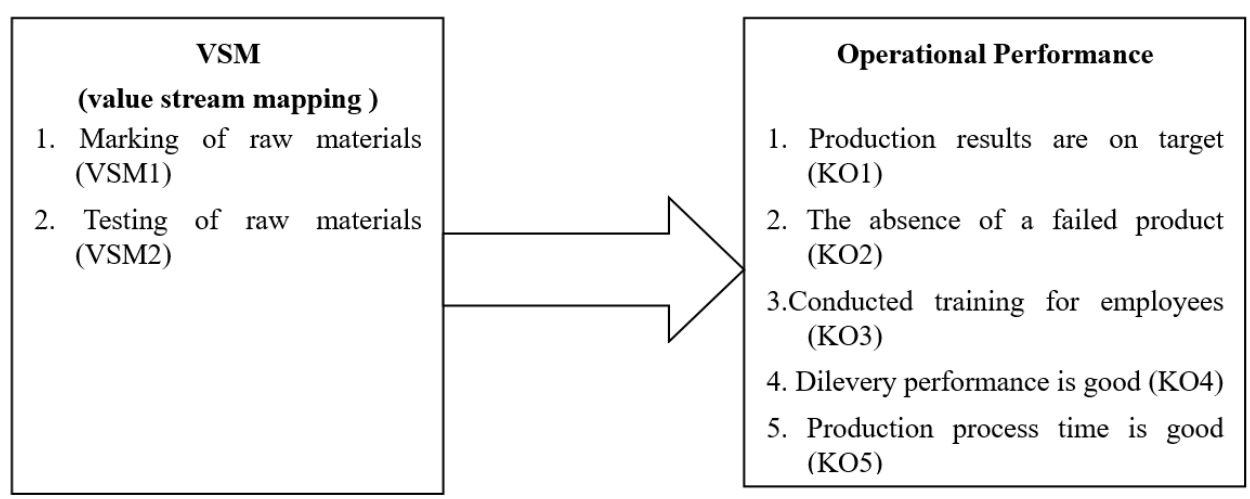

Image: 1. Framework

Sources: Gaspersz in Febiola (2011) and Gazpersz in Naibaho (2012) (Gaspersz, V., dan Avanti, 2011)

Figure 1. describes that the value stream mapping variable is measured from the Raw Material Marking (VSM1) indicator, Raw Material Testing (VSM2). Operational performance variables are measured from the indicator of production results according to the target (KO1), the absence of product failure (KO2), conducted training of employees (KO3), Dilevery performance is good (KO4), when the production process is good (KO5). Based on previous research and the framework of thought made, the hypotheses that are compiled are: H1: VSM (value stream mapping) has a positive effect on operational performance.

\section{Research Method}

The research method that I use in this study is causal associative research with a survey approach, for example by distributing questionnaires, structured interviews, and so on. Causal associative research is research that aims to determine the relationship of two or more variables. In this research a module can be built that can function to explain, predict and control a symptom, (Sugiyono, 2015). Mean while, according to (Ferdinand, 2014),Causality research is research that wants to find an explanation in the form of cause and effect between several concepts or several variables or strategies developed by management.

Table 1. Table of research operational variables

\begin{tabular}{|c|c|c|c|}
\hline Variable & Dimension & Indicator & Code \\
\hline $\begin{array}{l}\text { Value stram mapping } \\
\text { (VSM) } \\
\text { Value Stream Mapping is } \\
\text { an ideal tool as a first step } \\
\text { in carrying out the } \\
\text { process of change to } \\
\text { obtain lean } \\
\text { manufacturing conditions } \\
\text { or lean entreprises } \\
\text { (Goriwondo et al., 2011) }\end{array}$ & $\begin{array}{l}\text { 1. Marking of raw materials } \\
\text { 2. Testing of raw materials }\end{array}$ & $\begin{array}{l}\text { 1. Marking process is carried out for } \\
\text { each available raw material } \\
\text { 2. Quality raw material test results }\end{array}$ & VSM 1 \\
\hline $\begin{array}{l}\text { Operational Performance } \\
\text { (KO) } \\
\text { Company performance is } \\
\text { a complete view of the } \\
\text { state of the company for a } \\
\text { certain period of time, is } \\
\text { a result or achievement } \\
\text { that is influenced by the } \\
\text { company's operational } \\
\text { activities in utilizing the } \\
\text { resources owned } \\
\text { (Srimindarti, 2004) }\end{array}$ & $\begin{array}{l}\text { 1. Production results are on } \\
\text { target } \\
\text { 2. The absence of a failed } \\
\text { product } \\
\text { 3. Conducted training for } \\
\text { employees } \\
\text { 4. Dilevery performance is } \\
\text { good } \\
\text { 5. The production process } \\
\text { is good }\end{array}$ & $\begin{array}{l}\text { 1. The company is able to reach the } \\
\text { targeted sales level } \\
\text { 2. The company is able to produce } \\
\text { products that do not fail (good } \\
\text { product) } \\
\text { 3. The company always provides } \\
\text { training to existing employees } \\
\text { 4. The company is able to meet the } \\
\text { suitability of the delivery time of } \\
\text { the goods or the time that has been } \\
\text { promised } \\
\text { 5. The company reaches the } \\
\text { production time according to what } \\
\text { has been set by the company }\end{array}$ & $\begin{array}{c}\text { KO } 1 \\
\text { KOP } 2 \\
\text { KOP } 3\end{array}$ \\
\hline
\end{tabular}

Source: Data processed (2018)

Questionnaires for the two variables above use the interval scale (distance scale). Interval scale is an ordinal scale that has distance points in the regularity of ranking categories, and interval type data are included in quantitative data groups. 


\subsection{Population and Sample}

Population is a generalization area consisting of: objects / subjects that have certain qualities and characteristics that are determined by researchers to be studied and then draw conclusions. So the population is not just people, but includes all the characteristics / properties possessed by the subject or object, (Sugiyono, 2015). The population in the study consisted of 9 Production Departments, Foreman and Ast Foreman from each department with a population of 151 people, included because they were strategic positions that received training and members of the implementation team from the lean manufacturing system. Whereas at the operator level, the survey was not involved. The standard error chosen for this study was 5 percent which led to a 95 percent freedom level.

Table 2. research samples.

\begin{tabular}{|c|l|c|}
\hline No & \multicolumn{1}{|c|}{ Position } & Jumlah \\
\hline 1 & GM & 2 \\
\hline 2 & PLANT MANAGER & 3 \\
\hline 3 & MANAGER & 7 \\
\hline 4 & ASST. MANAGER & 8 \\
\hline 5 & SPV & 40 \\
\hline 6 & STAFF & 45 \\
\hline & AMOUNT & 105 \\
\hline
\end{tabular}

Source: Production employee data

\subsection{Data and Data Collection Methods}

The data used in this study are primary data. Primary data is data obtained directly from research subjects / respondents contained in the questionnaire, with respondents being the employees of the Pertiwi Agung production department. Data collection procedures and techniques used in this study are: 1) Questionnaire, Field research (survey), this technique is a way to collect the main data which is carried out directly at the research location to obtain data, information and other information. The instrument used was to give a questionnaire, by distributing it to the employees of PT. Pertiwi Agung which is the object of research. 2) Interview, used to check and obtain a more complete / comprehensive data related to the object. 3) Documentation, in this technique the researcher collects data related to the history or records needed in the study. An example is the data on the total population of employees at PT. Pertiwi Agung. Data analysis method The Structural Equation Modeling (SEM) method is a multivariate analysis that can analyze the relationship of variables in a complex way, the data analysis method used in this study consists of three stages, namely the stages of data testing, the stages of research regression analysis. The use of Structural Equation Modeling (SEM) makes it possible to test relationships between complex variables, to obtain a comprehensive picture of the whole model (Ghozali, 2005). Hypothesis testing is done using the AMOS version 22 program to analyze causality relationships in the proposed structural model between Independent and dependent variables at the same time check the validity and reliability of the overall research instrument.

\subsubsection{Hypothesis testing}

According to (Ferdinand, 2014) testing a model using SEM using the steps below that will be used for hypothesis testing.

3.2.1.1 Development of a theory based model.

As a theoretical model development, the research topic is explored in depth as hypothesized variables must be supported by a strong theoretical justification. That is because SEM will confirm the suitability of the data with the theory.

\subsubsection{Development of Path Diagrams.}

At this stage each latent construction is entered into the model and the measured indicator variable is latent construction. Although this identification can be demonstrated by equations, it is easier to represent this process with a diagram. The theoretical model that has been built will be illustrated in a path diagram to be estimated. In SEM modeling, researchers usually work with constructs or factors, which are concepts that have sufficient theoretical footing to explain various forms of relationships. Constructs that are built in flowcharts can be divided into two groups, namely exogenous constructs and endogenous constructs. Exogenous constructs are known as source variables or independent variables that are not predicted by other variables in the model. Constructs built in flowcharts can be divided into two groups, namely exogenous constructs and endogenous constructs. Exogenous constructs are known as source variables or independent variables that are not predicted by other variables in the model. From the research title, the influence of Value stream mapping (VSM) on operational performance at PT. The Great Pertiwi can be described in the Path Diagram as shown in Figure 2. 


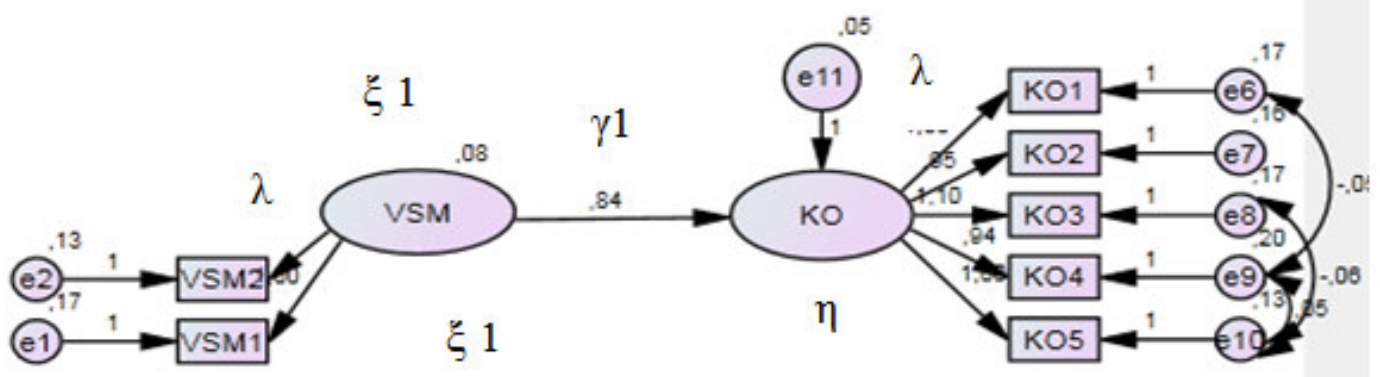

Figure 3. Path Diagram

The description of the Path Diagram Symbols can be seen in Table 3

Table 3. Description Path Symbol Diagram

\begin{tabular}{|l|l|}
\hline \multicolumn{1}{|c|}{ Symbol } & \multicolumn{1}{c|}{ Information } \\
\hline$\xi$ (Ksi) & Information Exogenous variable symbol (VSM) \\
\hline$\eta$ (Eta) & Endogenous variable symbol (Operational Performance) \\
\hline$\zeta$ (zeta) & Symbol for measuring errors in endogenous variables (latent variables) \\
\hline$\lambda($ lambda $)$ & Load factor symbol (factor loading) \\
\hline$\gamma($ Gamma) & The coefficient of influence of exogenous variables on endogenous variables \\
\hline$\varepsilon$ (Epsilon) & Measurement error in manifest variable \\
\hline
\end{tabular}

Source: (Sugiyono, 2011)

Table 4. Description of SEM Analysis Symbols

\begin{tabular}{|l|l|}
\hline Symbol & \\
\hline$\xi 1$ & Exogenous variable VSM Information \\
\hline QCP1 & Marking of raw materials (VSM1) \\
\hline QCP2 & Marking of raw materials (VSM2) \\
\hline$\xi 2$ & Exogenous variable VSM \\
\hline$\eta 1$ & Endogenous Variables Operational Performance \\
\hline KO1 & Production results are on target \\
\hline KOP2 & Absence of a failed product \\
\hline KOP3 & Conducted training for employees \\
\hline KOP4 & Dilevery performance is good \\
\hline KOP5 & Production time is good \\
\hline
\end{tabular}

Source: (Sugiyono, 2011)

3.2.1.3 Conversion of Path Diagrams into Equations

From Figure 3.1. Path Diagram obtained the following equation: Formulated to express causality between various constructs. The formula developed is: Endogenous variables = exogenous variables + exogenous variables + error $\mathrm{KO}=\gamma 1 \mathrm{VSM}+\varepsilon$

Where :

$$
\begin{aligned}
& \text { KOP }=\text { Operational Performance } \\
& \gamma 1 \gamma 2=\text { Regression coefficient } \\
& \text { QCP = Value stream mapping } \\
& \text { e = Error }
\end{aligned}
$$

\subsubsection{Selection of Input Matrix and Model Estimation}

The data input matrix used is the variance / covariance matrix or correlation matrix. The suitable sample size for SEM is 100-200. Whereas the minimum sample size is 5 observations for each parameter estimate. The model estimation available in the AMOS software or program is the Maximum Likehood Estimation Method, Generalized Least Square Estimation Method, Unweighted Least Square Estimation (ULS), Scale Free Least Square Estimation (SLS) and Asymptotically Distribution-Free Estimation (SLS).

3.5.3.5 Evaluate the Goodness of Fit

Criteria In this step the suitability of the model is evaluated, through evaluation of various Goodness-of-fit criteria.

1) Evaluation of SEM Assumptions, Normality by using a critical value of \pm 2.58 at a significance level of 0.01 . If the $\mathrm{Z}$-value is greater than the critical value, then it is suspected that the data distribution is not normal.

a) Outliers, are observations or data that have unique characteristics that look very different from observations, 
both for a single variable and combination variables.

b) Multicollinearity and Singularity, in statistics, multicollinearity (also called collinearity) is a phenomenon where one predictor variable in a multiple regression model can be a linear prediction of another with a degree of substance of accuracy. It is necessary to observe the determinants of the sample covariance matrix whose determinants are small or near zero indicate the presence of multicollinearity or sigularity, so that the data can be used for research.

2) Conformity Test and Statistical Test

To conduct a suitability test and a statistical test, several conformity indexes and cut-off values are needed to be used in testing a model.

a) X2-Chi-Square statistics, the smaller the better the model and accepted based on the probability with a cut-off value of $\mathrm{p}>0.05$ or $\mathrm{p}>0.10$.

b) RMSEA (The Root Mean Square Error of Approximation), is an index used to compensate for chi-square in large samples. RMSEA value which is small or equal to 0.08 is an index for the acceptance of the model based on degree of freedom.

c) GFI (Goodness of Fit Index), is a non-statistical measure that has a range of values from 0 to 1 . High values in this index indicate a "better fit".

d) AGFI (Adjusted Goodness of Fit Index), is a criterion that takes into account the weighted proportion of the variance of a sample covariance matrix. The recommended level is if AGFI has a value equal to or greater than 0.90 .

e) CMIN / DF (The Minimum Sample Discrepancy Function Devided with Degree of Freedom), is the chi-square statistic X2 divided by the degree of freedom so it is called X2 relative. A relative value of X2 less than 2.0 or 3.0 is an indication of acceptable models and data.

f) TLI (Tucker Lewis Indeex), is an incremental index comparing a model that is tested against a baseline model, where the recommended value as a reference for accepting a model is $\geq 0.95$ and a value close to 1 is very good fit.

g) CFI (Comparative Fit Index), a range of values of 0-1, where getting closer to 1 indicates the highest level of fit index.

3) Reliability and Variance Extract Test

a) Reliability test, where the accepted reliability value is $\geq 0.70$. Reliability tests in the Structural Equation Model (SEM) can be obtained through the following formula:

$$
\text { Construct reliability }=\frac{\left(\sum \text { Std.Loading }\right)^{2}}{\left(\sum \text { Std.Loading }\right)^{2}+\in . j}
$$

Where :

Standard Loading is obtained from standardized loading for each indicator obtained from computer calculation results. is the measurement error of each indicator.

b) Variance Extract, where the acceptable value is $\geq 0.50$, the formula used is as follows:

Variance Extract $(\mathrm{AVE})=\sum \frac{\text { StdLoading }}{\sum S t d L \text { oading } \in . j}$

Where :

Standard Loading is obtained from standardized loading for each indicator obtained from computer calculation results.

e. is the measurement error of each indicator (1-Std. Loading) ${ }^{2}$.

4) Validity Test

a) Convergent Validity

The items or indicators of a latent contract must be converged or shared (a high proportion of variants) and this is called convergent validity. To measure the construct validity can be seen from the value of the loading factor. In cases where high construct validity occurs, high loading values for a factor (latent construct) indicate that they converge at one point. The requirements must be met, first the loading factor must be significant. The standardized loading estimate must be equal to 0.05 or greater and ideally should be 0.70 .

b) Discriminant Validity Discriminant

Validity measures to what extent a construct is completely different from other constructs. The high value of discriminant validity provides evidence that a construct is unique and able to capture the phenomenon being measured. The way to test it is to compare the square value of $\operatorname{AVE}(\sqrt{A V E})$ with the correlation value between constructs. 
Model Interpretation and Modification

When the model has been accepted, the researcher can consider doing a modification of the model to improve the theoretical explanation or goodness-of-fit. If the model is modified, then the model must be cross-validated (estimated with separate data) before the modification model is accepted. Model measurement can be done with modification indices. The value of the modification indices is the same as the Chi-square decrease if the coefficient is estimated.

\section{Result And Discussion}

One of the data collection techniques in this study is to use a questionnaire distributed to all respondents of PT. Pertiwi Agung. This questionnaire consists of various statements made based on 7 indicators studied. The questionnaire was distributed to respondents totaling 105. Total 105 respondents had fulfilled the requirements for data processing, based on (Hair Jr et al., 2014) which stated that the number of samples followed the formula $5 \mathrm{x}$ the number of indicator variables so that in this study the minimum number of samples taken was $5 \times 7=28$ person.

Table 5. Duration of Work

\begin{tabular}{|c|c|c|}
\hline Age (Year) & Amount & Percentage \\
\hline$<5$ & 35 & $10 \%$ \\
\hline $6-10$ & 30 & $16 \%$ \\
\hline $11-20$ & 12 & $62 \%$ \\
\hline$>21$ & 28 & $12 \%$ \\
\hline Total & 105 & $100 \%$ \\
\hline
\end{tabular}

Source: Production HRD Data 2018

Table 5 Length of Work Respondents showed that respondents with a working period of more than 21 years totaled 28 respondents or $12 \%$. Respondents who have worked between 11 and 20 years amounted to 12 respondents or $62 \%$. Respondents with a work duration of between 6-10 years totaled 30 respondents or $16 \%$. Respondents who have worked less than 5 years are 35 respondents or $10 \%$. Thus the most respondents are those who have worked between $<5$ year.

Model Specifications and Test Validity and Reliability

The specification of the model is based on the theory that is the basis of this research. The latent variables in this study are divided into two, namely exogenous latent variables and endogenous latent variables. Exogenous latent variables are Value stream mapping (VSM), while endogenous latent variables are operational performance (KO).

- CFA Value stream mapping (VSM)

Validity Test with CFA Test or Construct Validity Test (indicator), which is measuring whether the construct (indicator) is able or not to reflect its latent variables. The results meet the criteria of a Critical Ratio $(\mathrm{CR})$ value $>1.96$ with Probability $(\mathrm{P})<0.05$. The sign for $* * *$ is significant $<0.001$.

CFA test or construct validity test, is intended to know that each indicator can explain the existing construct. Indicators used as a measure of research variables are indicators that have $p$ value $<0.05$ and loading factor $>0.5$, while indicators that have $\mathrm{p}$ value $>0.05$ and loading factor $<0.5$ are eliminated from the model, (Ghozali, 2014).

Confirmatory factor analysis functions to describe the relationship between the measured variable (observed variable) with its latent variable. In this case, CFA shows the contribution of the measured variable to the latent variable expressed by the loading factor. The latent variables tested in this analysis are the Value stream mapping (VSM) and Company Operational Performance (KO) variables.

According to (Ghozali, 2014)the first thing that needs to be seen is the significance value (P value) if more than 0.05 , then the indicator is removed from the model, the second is to see the standardized loading factor (Estimate value), if it is below 0.50 then the indicator is removed from the model because it is considered invalid. Value stream mapping (VSM) is one of the factors that determines operational performance (KO). The unidimensionality of these dimensions is tested through confirmatory factor analysis, the results of which are as shown in Figure 4.

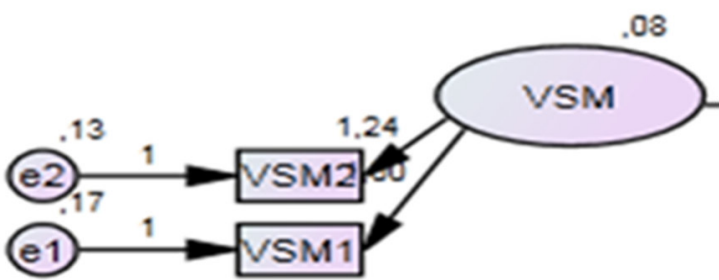

Figure 5. CFA Test of Value stream mapping (VSM) variables

In table 5, the Output Regression Weight of the Product Quality Control variable, on the P value (Probability), the probability values all show a sign of *** which means significant at the level of 0.001 this means less than 0.05 when seen from the Regression Weight, then the control variable Valid value stream mapping. 
Tabel 5. Probabilitas Value stream mapping(VSM)

\begin{tabular}{|l|l|l|r|r|r|r|c|}
\hline \multicolumn{1}{|c|}{ VSM } & & & Estimate & \multicolumn{1}{c|}{ S.E. } & \multicolumn{1}{c|}{ C.R. } & P & Label \\
\hline VSM1 & $<---$ & VSM & 1,000 & & & & \\
\hline VSM2 & $<---$ & VSM & 1,241 &, 337 & 3,679 & $* * *$ & par_1 \\
\hline & & & & & & & \\
\hline
\end{tabular}

Source: Processed Data (2018)

\section{- CFA Operational Performance (KO)}

The company's operational performance is an endogenous variable. Unidimensionality of these dimensions is tested through confirmatory factor analysis, the results of which are as shown in Figure 6.

Table 1. The capitals, assets and revenue in listed banks

Description for the above table.

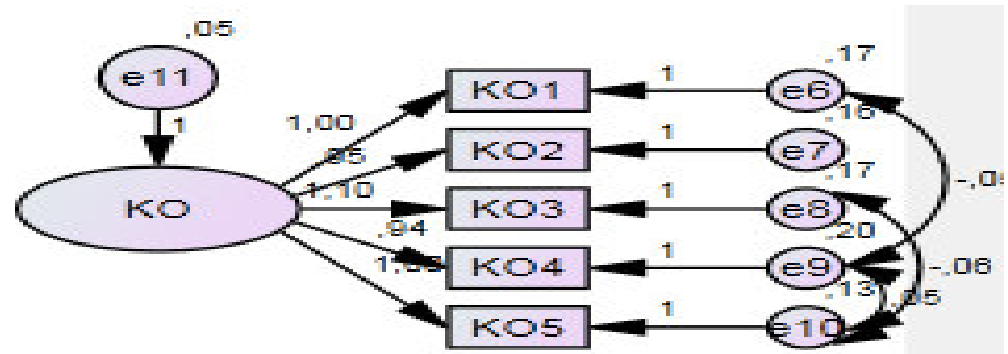

Figure 6. CFA Test of Operational Performance variables

Operational performance is an endogenous variable. Table 7. Indicates Output Regression Weight for Operational Performance variables at P (Probability), all probability values are shown *** which means significant at the level of 0.001 which means less than 0.05 , seen from the Regression Weight variable Operational Performance shows that the Operational Performance variable is valid.

Table 7. Probability of Operational Performance

\begin{tabular}{|l|l|l|l|l|l|l|l|}
\hline KO & & & Estimate & S.E. & C.R. & P & Label \\
\hline KO1 & $<---$ & KO & 1,000 & & & & \\
\hline KO2 & $<---$ & KO &, 948 &, 192 & 4,947 & $* * *$ & par_2 \\
\hline KO3 & $<---$ & KO & 1,096 &, 234 & 4,691 & $* * *$ & par_3 \\
\hline KO4 & $<---$ & KO &, 943 &, 251 & 3,762 & $* * *$ & par_4 \\
\hline KO5 & $<---$ & KO &, 998 &, 225 & 4,435 & $* * *$ & par_5 \\
\hline
\end{tabular}

Source: Data processed (2018)

In table 7 the Standardized Regression Weight variable of the Company's Operational Performance, the loading factor (Estimate) value is above 0.5 This shows that the operational performance indicators show the contribution of the measured variables with valid data results.

Table 8. Loading Factor (Estimate) Operational Performance (KO)

\begin{tabular}{|c|l|c|c|}
\hline KOP & & & Loading Factor (Estimate) \\
\hline KO1 & $<---$ & KO & 0,620 \\
\hline KO2 & $<---$ & KO & 0,613 \\
\hline KO3 & $<---$ & KO & 0,657 \\
\hline KO4 & $<---$ & KO & 0,565 \\
\hline KO5 & $<---$ & KO & 0,669 \\
\hline
\end{tabular}

Source: Data processed (2018)

- AVE and Construct Realibilty

Variance Extract (AVE), the acceptable value is $\geq 0.50$, the formula used is as follows: Variance Extract $(\mathrm{AVE})=$ $\sum \frac{\text { Std.Loading }}{2}$

Where :

Standard Loading is obtained from standardized loading for each indicator obtained from computer calculation results.

$\varepsilon . f$ is the measurement error of each indicator (1-Std. Loading) 2.

Construct reliability Test reliability, where the reliability value received is $\geq 0.70$. Reliability tests in the Structural Equation Model (SEM) can be obtained through the following formula: 


$$
\text { Construct reliability }=\frac{\left(\sum \text { Std.Loading }\right)^{2}}{\left(\sum \text { Std } \cdot \text { Loading }\right)^{2}+\in . j}
$$

Where :

Standard Loading is obtained from standardized loading for each indicator obtained from computer calculation results.

$$
\epsilon \cdot j \text { is the measurement error of each indicator. }
$$

Table 9. Variance Extract (AVE) \& Construct Reliability

\begin{tabular}{|c|c|c|}
\hline Variabel & AVE & Construct Reliability \\
\hline Value stream mapping & 0.419 & 0.587 \\
\hline Operating performance & 0.410 & 0.735 \\
\hline
\end{tabular}

\section{- Test for Assumption of Normality}

One of the requirements in SEM, especially if the data is estimated by the Maximum Likelihood estimation technique is data normality. To test data normality, statistical tests can be used such as observing the skewness of the data used.

Normality test aims to test whether the regression model of confounding or residual variables has a normal distribution, (Ghozali, 2005).The requirement to get a good regression model is the data is normal or close to normal. Data is stated as normal distribution if it is significantly greater than $5 \%$ or 0.05 (Priyatno, 2008). One of the requirements in SEM, especially if the data is estimated by the Maximum Likelihood estimation technique is data normality. To test data normality, statistical tests can be used such as observing the skewness of the data used. Evaluation of multivariate normality is done by using the criterion criterion ratio (cr) of multivariate in kurtosis, if it is in the range of -2.58 to 2.58 , it means that the data are normally normally distributed multivariate (Haryono, 2017).

Table 10. Value of Assessment of Normality

\begin{tabular}{|l|c|c|r|r|r|r|}
\hline \multicolumn{1}{|c|}{ Variable } & \multicolumn{1}{c|}{$\min$} & \multicolumn{1}{c|}{$\max$} & \multicolumn{1}{c|}{ skew } & c.r. & kurtosis & c.r. \\
\hline VSM1 & 3,000 & 5,000 &,- 802 & $-3,355$ &,- 815 & $-1,705$ \\
\hline VSM2 & 3,000 & 5,000 &, 375 & 1,567 &,- 033 &,- 069 \\
\hline KO1 & 3,000 & 5,000 &,- 021 &,- 086 & $-1,177$ & $-2,462$ \\
\hline KO2 & 3,000 & 5,000 &, 311 & 1,299 &,- 215 &,- 450 \\
\hline KO4 & 3,000 & 5,000 &, 032 &, 133 &, 274 &, 574 \\
\hline KO5 & 3,000 & 5,000 &, 384 & 1,606 &, 438 &, 915 \\
\hline Multivariate & & & & & 2,083 & 2,490 \\
\hline
\end{tabular}

Source: Primary Data Processed Using IBM SPSS Amos

Table 10 shows the overall results (multivariate) normal, because the multivariate number 2,490 is in the range of -2.58 to 2.58 . Interpretation of results if the data is not normal needs to be done deleting outlier data so that later it is expected to get data that meets the normality assumption. Oulier data in this study can be seen through the Mahalanobis d-squared output. This step is suitable for research that uses large data.

\section{- Model Suitability Test}

The purpose of the test fit model or Goodnest of fit is to find out some right manifest variables (indicator variables) can explain the existing latent variables. The Goodness of Fit test or the model feasibility test is used to measure the accuracy of the sample regression function in estimating the actual value. Statistically the Goodness of Fit test can be done through the measurement of the coefficient of determination, the statistical value of $F$ and the statistical value of t. According to (Ghozali, 2011), a statistical calculation is called statistically significant if its statistical test value is in a critical area (the area where Ho is rejected). On the other hand, the statistical calculation is called insignificant if the statistical test value is in the area where Ho is received.

Modification of the model is done by connecting or covariating between variables on the model or removing indicator variables, as recommended by AMOS (on the Modification Indices output).

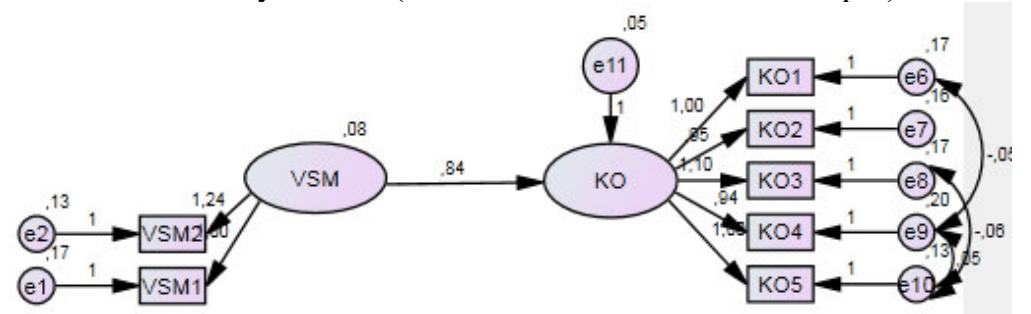

Figure 7 Full SEM Model after Modification

According to (Ghozali, 2012) as a whole Goodness of fit can be assessed based on a minimum of 5 criteria. 
In empirical research, a researcher is not required to meet all the criteria of goodness of fit, but depends on the judgment or decision of each researcher. Recommendations for getting a fit model are shown in the appendix After eliminating and connecting as recommended by the modification indices, the model can be seen in Figure 7.

Table 11. Goodness of Fit After Model Modification

\begin{tabular}{|l|l|l|l|}
\hline \multicolumn{1}{|c|}{ Goodness of Fit } & Cut of Value & Hasil sesudah modifikasi & Keputusan \\
\hline Probabilitas Chi Square & $\geq 0,05$ & 0,626 & Good Fit \\
\hline CMIN/DF & $\leq 2,00$ & 0,803 & Good Fit \\
\hline GFI & $\geq 0,90$ & 0,979 & Good Fit \\
\hline AGFI & $\geq 0,90$ & 0,940 & Good Fit \\
\hline CFI & $\geq 0,90$ & 1,000 & Good Fit \\
\hline TLI & $\geq 0,90$ & 1,000 & Good Fit \\
\hline NFI & $\geq 0,90$ & 0,957 & Good Fit \\
\hline IFI & $\geq 0,90$ & 1,000 & Good Fit \\
\hline RMSEA & $\leq 0,08$ & 0,000 & Good Fit \\
\hline RMR & $\leq 0,05$ & 0,009 & Good Fit \\
\hline
\end{tabular}

Source: Appendix

Table 11. shows the goodness of fit after the model modification. More than 5 indicators are in accordance with the expected criteria.

\section{- Hypothesis Test (Analysis of Influence of Variables)}

After overall a structural model can be considered fit, the next process is to look at the effect of the independent variable with the dependent variable.

Table 12. Regression Weights: Model Modifications

\begin{tabular}{|l|l|l|r|r|r|r|r|}
\hline & & & Estimate & S.E. & C.R. & P & Label \\
\hline KO & $<---$ & VSM &, 841 &, 254 & 3,305 & $* * *$ & par_6 \\
\hline
\end{tabular}

Source: Amos analysis results

The basis for decision making is if the $\mathrm{P}$ value (Probability) $>0.05$ then $\mathrm{H} 0$ is accepted or there is no influence, if the $\mathrm{P}$ value (Probalitias) $<0.05$ then $\mathrm{H} 0$ is rejected or there is an influence (Santoso, 2015)

Based on Table 12, it can be concluded as below:

1) There is a significant influence between Employee Competence on High Performance Culture. This is because the probability value is less than $0.05(* * *<0.05)$. A positive estimate value of 0.841 means that the effect is positive

\section{- Structural Model Analysis Path}

analysis is an extension of linear regression analysis. Path analysis is the use of regression analysis to estimate causality relationships between variables that have been predetermined based on theory. 1) Structural equality As explained earlier that the model used in this study is a modified model. In addition, based on the results of a model match where five indicators are used, namely Chi Square, RMSEA, TLI, CFI, and IFI, the obtained model can be declared fit. The structural models formed are:

$\mathrm{KO}=0.84 \mathrm{VSM}+\mathrm{e}$

Where:

$\mathrm{KO}=$ Company Operational Performance

$\mathrm{VSM}=$ Vulue stream mapping

$\mathrm{e}=$ error Based on the model,

it can be seen that each increase in Cumul stream stream is one unit, it will increase Operational Performance by 0.84 units

2) Direct influence This analysis is to determine the magnitude of the direct effect coefficient, so it can be known whether the mediating variable mediates the effect of the independent variable on the dependent or not. Table 13 shows the results of the influence of product quality control and the quality of production machinery on the company's operational performance.

Table 13. Direct effects

\begin{tabular}{|l|c|}
\hline & Vulue stream mapping \\
\hline Operational Performance & 0.841 \\
\hline
\end{tabular}

Source: Model Modification

\section{Conclusion}

Based on the results of SEM analysis, this section will discuss the results of calculations that have been made. This study aims to determine the effect of Value steam mapping (VSM) on operational performance. Testing is shown through existing hypotheses so that they can find out how the influence of each construct on the other constructs. 


\section{Reference}

Ferdinand, A. (2014). Pedoman Penelitian Untuk Penulisan Skripsi Tesis dan Disertasi Ilmu Manajemen: Metode Penelitian Manajemen: Semarang: Badan Penerbit Universitas Diponegoro.

Gaspersz, V., dan Avanti, F. (2011). (2011). Organizational Excellence: Systematic Continuous Improvement and Innovation. Bogor: Vinchristo.

Ghozali, I. (2005). Analisis Multivariate dengan program SPSS. Semarang: Badan Penerbit Universitas Diponegoro.

Ghozali, I. (2011). Aplikasi multivariate dengan program IBM SPSS 19. Semarang: Badan Penerbit Universitas Diponegoro.

Ghozali, I. (2012). Imam Ghozali. 2012. Aplikasi Analisis Multivariate Dengan Program Ibm Spss, 20.

Ghozali, I. (2014). Ekonometrika: Teori, konsep dan aplikasi dengan IBM SPSS 22. Semarang: Badan Penerbit Undip.

Goriwondo, W. M., Mhlanga, S., \& Marecha, A. (2011). Use of the value stream mapping tool for waste reduction in manufacturing. Case study for bread manufacturing in Zimbabwe. Proceedings of the 2nd International Conference on Industrial.

Hair Jr, J. F., Sarstedt, M., Hopkins, L., \& Kuppelwieser, V. G. (2014). Partial least squares structural equation modeling (PLS-SEM). European Business Review.

Haryono, S. (2017). Metode Sem untuk Penelitian Manajemen dengan Amos Lisrel PLS. Luxima: Jakarta.

Hines, P., \& Taylor, D. (2000). Going lean. Cardiff, UK: Lean Enterprise Research Centre Cardiff Business School, $3-43$.

Liker, J., \& Meier, D. (2006). The Toyota Way Fieldbook: a Practical.

Priyatno, D. (2008). Mandiri Belajar SPSS (Statistical Product and Service Solution). MediaKom, Yogyakarta.

Rahani, A. R., \& Al-Ashraf, M. (2012). Production flow analysis through value stream mapping: a lean manufacturing process case study. Procedia Engineering, 41, 1727-1734.

Santoso, S. (2015). AMOS 22 untuk Structural Equation Modelling. Elex Media Komputindo.

Srimindarti, C. (2004). Balanced Scorecard Sebagai Alternatif untuk Mengukur Kinerja. Fokus Ekonomi, 3(1), $52-64$.

Sugiyono, P. (2011). Metodologi penelitian kuantitatif kualitatif dan R\&D. Alpabeta, Bandung.

Sugiyono, P. (2015). Metode penelitian kombinasi (mixed methods). Bandung: Alfabeta.

Womack, J. P., \& Jones, D. T. (1996). Beyond Toyota: how to root out waste and pursue perfection. Harvard Business Review, 74(5), 140-172. 